\title{
The Question of Welfare State in Natural Law Theories
}

\author{
YUKI HARUYAMA
}

\section{Introduction}

Many scholars, not only historians, but also social scientists, have contributed to the research in the origins of the idea of ,welfare state". According to the conventional interpretation it appeared at the end of the $19^{\text {th }}$ century and became a powerful agenda of social policy in the era after World War II. In general, the welfare state or the Sozialstaat is considered as a state which aims at the promotion and maintainance of national welfare and takes on also the responsibility for the well-being of its citizens. ${ }^{1}$ In particular, a welfare state is committed to combat poverty among its citizens, provide guarantee for their level of living and equality in the distribution of economic benefits. Moreover, a welfare state has the authority to intervene in many aspects of civil life in order to attain those purposes.
Students of welfare state have often focused mainly on the development of social welfare policy in the late the $19^{\text {th }}$ century and in the early $20^{\text {th }}$ century, and then created some typologies of the welfare state. The best known is the typology of the Danish social scientist, Gøsta Esping-Andersen. ${ }^{2}$ Apart from the historical studies of welfare state in western and northern European countries and in the United States, there has recently appeared new research in the post-communist countries of Eastern Europe. Even though western scholars believe that these East-European works have not crossed the broderline of the $19^{\text {th }}$ century, the opposite is true. The new research by Jakub Rákosník and others has focused mainly on state social policies in the $20^{\text {th }}$ century. ${ }^{3}$

1 For various definitions and historical accounts, see Gerhard A. RitTer, Der Sozialstaat. Entstehung und Entwicklung im internationalen Vergleich, Munich 1991, p. 1-28; Gøsta Esping-Andersen, The Three Worlds of Welfare Capitalism, Cambridge 1990; Mohammed RAssem, Woblfahrt, Wobltat, Wohltätigkeit, Caritas, in: Otto Brunner - Werner Conze - Reinhart Koselleck (edd.), Geschichtliche Grundbegriffe: Historisches Lexikon zur politisch-sozialen Sprache in Deutschland 7, Stuttgart, 1992, p. 595-636, in particular p. 632-636.

2 G. Esping-Andersen, The Three Worlds, p. 9-34, especially p. 26-29. Esping-Andersen's typology, however, brought about the discussion on its applicability to the former communist countries. According to D. Szikra and B. Tomka, some scholars argue that his typology does not compass those countries. On the other hand, there are scholars who recognise a possibility to utilise it. Dorottya Szinra - Béla Tomка, Social policy in east central Europe. Major trends in the twentieth century, in: Alfio Cerami - Pieter Vanhuysse (edd.), Post-Communist Welfare Pathways. Theorizing Social Policy Transformations in Central and Eastern Europe, Basingstoke 2009, p. 17-34, here p. 18.

3 See Milan HlavačKa - Pavel Cibulka (edd.), Chudinství a chudoba jako sociálně historický fenomén, Prague 2013; Jakub Rákosník - Igor Tomeš, Sociálni stát v Československu. Právné-institucionální 
To sum up, the research in the origins of welfare state has already made a considerable progress but the historical investigations rarely venture to explore the early modern prehistory of this concept. J. Innes has already pointed out: „In the intervening period...there exists relatively little in the way either of synthesis or of comparative study". ${ }^{4}$ However, it has been already argued - mainly in German historiography - that the idea of welfare state (Woblfahrtsstaat), had been formed already in the era of enlightened absolutism, namely in the reign of Frederick II in Prussia and Joseph II in the Habsburg Monarchy. ${ }^{5}$ More recent work written by Klaus Wohlrab has located the origins of welfare state in the era of late natural law. ${ }^{6}$ However, Wohlrab does not differentiate between natural law thinkers and cameralists. Regrettably, his interpretation is also skewed by the insistence on the discontinuation between the ,older natural law" and ,new natural law". According to this theory, the „older natural law“, as it existed up to about 1790, was an ideology supporting absolute monarchy, whereas the "new natural law“ was supportive of liberal ideology.

In earlier historical works, it was mainly Christian Wolff who was given the credit for inventing the concept of welfare state and combining it with the idea of enlightened absolutism. ${ }^{7}$ This conclusion

vývoj v letech 1918-1992, Prague 2013; Milan HlavačKa - Pavel Cibulka, Sociální myšlení a sociální praxe v českých zemich 1781-1939, Praha 2015; Pavel Maršále k, Právo a společnost, Prague 2008, p. 88; The bibliography of a lot of these recent researches is attached to the above mentioned book. A. Cerami - P. Vanhuysse (edd.), Post-Communist Welfare Pathways, p. 256-286.

4 Joanna Innes, State, church and voluntarism in European welfare, 1690-1850, in: Hugh Cunningham - Joanna Innes (edd.), Charity, Philanthropy and Reform. From the 1690s to 1850, London 1998, p. 15-65, here 15 .

5 For instance, O. Hintze mentioned the principle of Frederickian state from perspective of the material welfare. According to him, the monarch knew precisely that political power could not exist for long time without a certain amount of economic welfare. Therefore, the monarch was to be careful to keep the balance of interest between the demesne lords (Gutsherren) and tenant farmers of the demesne (Domänenpächter), or implement measures about corn price in order to keep it at appropriate price. Otto Hintze, Geist und Epochen der preußischen Geschichte, in: Gerhard Oestreich (ed.), Regierung und Verwaltung. Gesammelte Abhandlungen zur Staats-, Rechts- und Sozialgeschichte Preussens 3, Göttingen 1967, p. 1-29, here p. 19. For the welfare policy in the reign of Frederick II in Prussia, see also Herbert Uppendahl, Eudämonismus und Woblfahrtsstaat, Archiv für Rechts- und Sozialphilosophie 64, 1978, p. 205-222, especially p. 218-220. For the description of welfare state in the Habsburg Monarchy, see Karl Aснам, Nachwort. Sonnenfels und seine Zeit-Eine Vergegenwärtigung, in: Hildegard Kremers (ed.), Joseph von Sonnenfels. Aufklärung als Sozialpolitik, ViennaKöln-Weimar, 1994, p. 227-247; Helmut Reinalter (ed.), Lexikon zum Aufgeklärten Absolutismus in Europa. Herrscher - Denker - Sachbegriffe, Vienna-Köln-Weimar, 2006, p. 62-65, especially p. 63.

6 Klaus Wohlrab, Armut als Staatszweck. Die politische Theorie der Armut im deutschen Naturrecht des 18. und 19. Jahrbunderts, Goldbach 1997.

7 Peter Badura, Das Verwaltungsrecht des liberalen Rechtsstaates. Methodische Überlegungen zur Entstehung des wissenschaftlichen Verwaltungsrechts, Göttingen, 1967, p. 31; Hanns-Martin Bachmann, Die naturrechtliche Staatslehre Christian Wolfs, Berlin 1977, p. 123-126, 206. 
rests mainly on what Wolff said about the goals of political association in his German Politics. In it Wolff would include welfare among the principles of civic morality. For example he would claim, „Do what promotes the common welfare and maintain the common security ", 8 or „Do what promotes the welfare of society, refrain from what is obstructive or even disadvantageous for you “. 9 These early German works included also a more detailed definition of what "welfare“ is: "The welfare consists in the enjoyment of alimentation, public peace and security“. ${ }^{10}$ These discoveries compelled the German economist G. Habermann to assert that it was the state, i.e. the ruler, his officers and the codes of laws, who judged what could contribute to the common good, because the subjects were supposed to be unable to decide this complex question. ${ }^{11}$ This line of research had already proved that the state was supposed to be committed to maintain welfare, and then use it for the benefit of all its citizens. This section of research was based on the police ordinances, „Polizeiordnungen“, or the early social facilities such as work houses. Their conclusions strengthened the image of an absolutist state in which the social disciplining operates on the basis of vertical power-relations. ${ }^{12}$

This article shall contribute to this research by exploring the arguments used by early modern thinkers in support of their conviction that the state should commit itself to social care and charity. The early modern thinkers provided two reasons to support this argument. Firstly, they claimed that charity was not only a means to promote public happiness, but also a means to make oneself a better per-

8 "Tue, was die gemeine Woblfahrt befördert und die gemeine Sicherheit erhält." Quoted from, M. RAsSEM, Wohlfahrt, p. 617.

9 "Tue, was die Wohlfahrt der Gesellschaft befördert, unterlass, was ibr hinderlich oder sonst nachteilig ist." Quoted from, Gerd Habermann, Wohlfahrtsstaat - einst und jetzt. Motive des „aufgeklärten Despotismus", Jahrbuch für die Ordnung von Wirtschaft und Gesellschaft 39, 1988, p. 91-109, here p. 96. „Die Wohlfahrt eines Staats aber (salus civitatis) bestehet in dem Genuss des hinlänglichen Lebensunterhalts, der Ruhe und der Sicherheit". Quoted from, M. Rassem, Wohlfahrt, p. 617.

G. Habermann, Wohlfahrtsstaat, p. 96.

12 As for the concept of „Sozialdisziplinierung“, Gerhard Oestreich, Strukturprobleme des europäischen Absolutismus, Vierteljahrschrift für Sozial- und Wirtschaftsgeschichte 55, 1968, p. 329-347. As for the history of poor-relief in Germany in terms of "Sozialdisziplinierung“, see Robert JüTte, Disziplinierungsmechanismen in der städtischen Armenfürsorge der Frühneuzeit, in: Christoph Sachsse - Florian Tennstedt (edd.), Soziale Sicherheit und soziale Disziplinierung. Beiträge zu einer historischen Theorie der Sozialpolitik, Frankfurt am Main 1986, p. 101-118; Christoph SAchsse - Florian Tennstedt, Geschichte der Armenfürsorge in Deutschland, Bd. I. Vom Spätmittelalter bis zum 1. Weltkrieg, Stuttgart $1998^{2}$. As for the history of the work house in Austria in early modern age, Hannes STEKL, „Labore et fame“-Sozialdisziplinierung in Zucht-und Arbeitshäusern des 17. und 18. Jahrbunderts, in: Christoph Sachsse - Florian Tennstedt (edd.), Soziale Sicherheit und soziale Disziplinierung. Beiträge zu einer historischen Theorie der Sozialpolitik, Frankfurt am Main 1986, p. 119-147. 
son. For instance, the influential German philosopher Moses Mendelssohn insisted, „so, it is not advisable, for example, that the state undertakes all obligations of the philanthropy, even the distributing of charity, and change them into public establishments. "13 According to him, the charity belonged to religion, and therefore could not be coerced by law. People had to do charity on their own free will. ${ }^{14}$ Otherwise, the givers could not attain happiness, and they would consider themselves oppressed by the state. ${ }^{15}$

Secondly, private charity remained still an essential resource of welfare in the early modern age. Recent studies on the history of welfare emphasise the significance of other agents than the state, especially the voluntary associations, which were motivated by philanthropy. This is sometimes called „mixed economy of welfare“. ${ }^{16}$ This concept is based on discussions about the social policy in Britain, which occurred in the late 1970s. In this discussion it was emphasised that the state is not the only provider of social care. In response to post-War motto which said that the state should take care of its citizens "from the cradle to the grave", it was emphasised that this task could be taken over by other agents. ${ }^{17}$ From this perspective, historians also ceased to focus only on the public facilities of the state and began to pay attention to private institutions.

This article seeks to prove that the idea of welfare state had been discussed even in early works of classical authors of natural law. However, I will also inquire what these authors really said about welfare and how they shaped their argument. I will dicsuss the works of Samuel von Pufendorf, Christian Wolff and the Cameralists

13 „Es ist z. B. nicht rathsam, dass der Staat alle Pfichten der Menschenliebe, bis auf die Almosenpflege, übernehme, und in öfentliche Anstalten verwandele". Moses Mendelssohn, Jerusalem oder über religiöse Macht und Judenthum, Berlin 1783, p. 23. As for Mendelssohn's life and his thought, David Sorkin, The Religious Enlightenment. Protestants, Jews, and Catholics from London to Vienna, Princeton-Oxford 2008, p. 165-212. As for the influence of his thought in the Habsburg Monarchy, especially in Bohemia, Ivo Cerman - Rita Krueger - Susan Reynolds (edd.), The Enlightenment in Bohemia. Religion, Morality and Multiculturalism, Oxford 2011.

M. Mendelssohn, Jerusalem, p. 23.

15 Ibidem.

16 G. Finlayson is regarded as a pioneer in the historical researches of poor-relief and welfare politics in Britain after the 19th century by his making good use of the concept of mixed economy of welfare. In his work he emphasises on the importance of self-help, mutual aid and voluntarism among citizens as factors of welfare in Britain. Geoffrey Finlayson, Citizen, State, and Social Welfare in Britain 1830-1990, Oxford 1994. See also Joanna Innes, The mixed economy of welfare in early modern England: assessments of the options from Hale to Maltus, in: Martin Daunton (ed.), Charity, Self-Interest and Welfare in the English Past, London 1996, p. 139-180.

17 Sheila B. Kamerman, The new mixed economy of welfare. Public and private, Social Work 28, 1983, p. 5-10; Jane LEwis, Welfare state or mixed economy of welfare?, History Today 45, 1995, p. 4-6; Michael B. Katz - Christoph Sachsse (edd.), The Mixed Economy of Social Welfare. Public/ Private Relations in England, Germany and the United States, the 1870's to the 1930's, Baden-Baden 1996. 
Johann H. G. von Justi and Joseph von Sonnenfels. These authors were chosen because they had some influence on social policies in the Habsburg Monarchy and their work largely contributed to social reconstruction of the country after the disastrous famine of 1770 to 1772 . It would be also necessary to examine the works of Christian thinkers who inspired the Josephine idea of a practical pastoral activity but this enterprise must be dealt with later. However, it should not be forgotten that even Josephine concpetion of Christian life urged people to commit themselves to charity. This conception drew on Ludovico Antonio Muratori and Augustin Zippe.

\section{Samuel von Pufendorf ${ }^{18}$}

Following the disaster of the Thirty Years War, many secular thinkers tried to desacralise laws and politics. ${ }^{19}$ One of the famous contemporary thinkers, Pufendorf constructed the theory of state-building based on the 'desecrated' social contract under the natural law ${ }^{20}$ and on Thomas Hobbes's anthropological considerations on human nature. ${ }^{21}$ Pufendorf's theory became quite popular in German speaking territories, as well as in the Habsburg Monarchy. Joseph II allegedly also received some lessons in his theory. ${ }^{22}$

In Pufendorf's theory of state-building, the purpose of state was to ensure safety for the members of state and to protect them from danger which could be rise from human passions such as ambition, lust of power and other selfish desires which could disturb the purpose of state. ${ }^{23}$ Thus, behaving selfishly would make people exposed to a serious threat. Hence, it would be necessary for humans to avoid it, and then necessity would compel them to establish a state, which could cultivate and change them into "citizens" through discipline. ${ }^{24}$ Based on his assumption of human weaknesses, Pufendorf formulated

18 This article uses English translation of Pufendorf's works as following: Samuel von PufEndorf, Of the Law of Nature and Nations Eight Books, Oxford 1710 (De Jure Naturae et Gentium 1672); IDEM, The Whole Duty of Man according to the Law of Nature, London 1735 (De Officio Hominis et Civis Juxta Legem Naturalem 1673).

19 D. Saunders applies the concept of ,juridification“, which Jürgen HaBERmas in his work, The Theory of Communicative Action, develops in order to explain the unification of „Lebenswelt" through law, into early modern Europe in the post era of the Thirty Years War, and then Saunders shows the several changes of religious factor in the juridical philosophy. David SAUnders, Juridifications and religion in early modern Europe. The challenge of a contextual history of law, Law and Critique 15, 2004, p. 99-118.

20 Ian Hunter, Rival Enlightenments. Civil and Metaphysical Philosophy in Early Modern Germany, Cambridge 2001.

21 Thomas Benme, Samuel von Pufendorf. Naturrecht und Staat, Göttingen 1995, p. 115.

22 Derek Beales, Enlightenment and Reform in Eighteenth-Century Europe, London-New York 2005, p. 271.

23 T. Beнme, Samuel von Pufendorf, p. 116.

24 Ibidem, p. 117. 
the several steps of state-builing from „the multitude" (multitudo) to the election of the ruler to whom Pufendorf would give the sovereign power, „summum imperium“. At the last phase of state-building, the rulers, would bind themselves to guarantee peace and safety for the subjects, and the subjects would bind themselves to "yield them faithful obedience " ${ }^{25}$

As Jerome B. Schneewind explains, the concept of duties and rights played a central role in Grotius's thought, and the Grotian tradition, namely the dichotomous classification of perfect right and duty versus imperfect right and duty, had also some bearing on Pufendorf's conception of natural law. ${ }^{26}$ Pufendorf claimed that there were the duties which would not be coerced by law and force, and which were not always necessary for the preservation of human society, but just for rendering their society comfortable and convenient. ${ }^{27}$ These duties were defined as the imperfect duties and they included „compassion, liberality, beneficence, gratitude, hospitality“, and, he continued, ,in one word all that is contained under that comprehensive name of charity, or humanity..." ${ }^{28}$ The fulfillment of imperfect duties was to be done by the conscience and honour of human. In short, the duty of charity was considered as being a part of morals, not law. In addition to the imperfect duties, there were the imperfect rights which corresponded with imperfect duties of other people. ${ }^{29}$ The imperfect rights, however, could turn into perfect rights but only if the bearer of rights had his life threatened. ${ }^{30}$

Based on the concept of duties and rights, Pufendorf made his argument on the role of rulers in the state. The rulers had various obligations toward the subjects. According to him, the rulers were obligated to understand everything what was needed to discharge their duties. ${ }^{31}$ For example, in order to keep the state in peace, it was necessary that will and passions of the subjects were moderated. Hence, the rulers were to maintain the public discipline. $^{32}$

As for the social care, the rulers were not obligated to cover the living costs of their subjects. It was only up to the ruler's moral judgement whether they would perform the duty of charity. Therefore, they had to provide the alimentation of their subjects only in case of calamities when the

S. Pufendorf, Of the Law of Nature, 7. 2, § 8.

Jerome B. SchneEwind, Pufendorf's place in the history of ethics, Synthese 72, 1987, p. 123-155; IDEM, The Invention of Autonomy. A History of Modern Morality, Cambridge 1998, p. 118-140.

S. Pufendorf, The Whole Duty of Man, 1, 2, § 14.

Ibidem.

Ibidem.

Ibidem.

S. Pufendorf, Of the Law of Nature, 7, 9, § 2.

Ibidem, $§ 4$. 
subjects would not be able to take care of themselves on their own..$^{33}$ However, „the strength of a state consists in the valour and the wealth of the subjects", therefore, the rulers were supposed to guarantee that the fortunes of their subjects multiply. ${ }^{34}$

Thus, it can be argued that the rulers were supposed to intervene only under the condition that the subjects had their lives threatened. However, this rule would apply only if the subjets' poverty was not caused by their own vice or idleness, but by unexpected disasters. On other occasions than this, the rulers were only supposed to encourage the subjects to work and increase their wealth on their own.

\section{Christian Wolff}

As scholars of the enlightened absolutism have insisted so far, it is said that Christian Wolff made a theoretical system of welfare state based on the geometric deduction on obligations of state and rulers through the natural law. According to H. Reinalter, Wolff's concept of the state, namely the state as ,an establishment for the promotion and safety of human's happiness", appeared in the state policy of Joseph II. ${ }^{36}$ Thus, it has been often considered to be the feature of enlightened absolutist state that the state could extend the authority into all the spheres of life for the purpose and the promotion and maintenance of subjects' welfare under the influence of his thought. ${ }^{37}$

As for the state's commitment into the social care, Wolff argued in the section 420, 'De copia rerum necessariarum, et voluptuariarum', in his Latin work Jus naturae as follows: „ruler of state is obligated to take care, not to neglect to supply all members of state with an abundance of things of food, clothing, shelter and necessity for comfortableness and pleasure“. ${ }^{38}$ According to him, a well-established state was to be full of necessary,

33 Ibidem, § 11.

34 Ibidem.

35 This article uses Wolff's works as following: Christian WoLFF, Jus naturae methodo scientifica pertractatum, Bd. VIII, Halle 1748; IDEM, Vernünffige Gedancken von Gott, der Welt und der Seele des Menschen, Auch allen Dingen überhaupt, Halle 1752; IDEM, Vernünftige Gedancken von der Menschen Thun und Lassen, zu Beförderung ibrer Glückseelighkeit, Halle 1752; IDEM, Grundsätze des Natur- und Völkerrechts, worin alle Verbindlichkeit und alle Rechte aus der Natur des Menschen in einem beständigen Zusammenhange hergeleitet werden, Halle 1769.

36 „Eine Einrichtung zur Förderung und Sicherung der Glückseligkeit des Menschen“. H. Reinalter (ed.), Lexikon, p. 63.

37 Karl H. Metz, Staatsraison und Menschenfreundlichkeit. Formen und Wandlungen der Armenpflege im Ancien Regime Frankreichs, Deutscblands und Großbritanniens, Vierteljahrschrift für Sozial- und Wirtschaftsgeschichte 72, 1985, p. 1-26. By contrast, J. G. Backhaus approaches to Wolff's thought on the social care by the state from the perspective of subsidiarity. Jürgen G. BacкHAUs, Christian Wolf on subsidiarity, the division of labor, and social welfare, European Journal of Law and Economics 4, 1997, p. 129-146.

38 „Rectori civitatis curae esse debet, ne desit rerum ad victum, amictum, habitationem, vitaeque commoditatem ac jucunditatem necessariarum copia omnibus sufficiens. " Ch. WolfF, Jus naturae, §420. 
useful and pleasurable things otherwise it would suffer from imperfection. ${ }^{39}$ In other words, the purpose of state could not be fulfilled without sufficiency of sustenance, comfortableness and pleasure..$^{40}$ However, the nature itself did not provide everything that people needed. Therefore he thought that the state was to take care of providing work for its subjects and making them diligent. ${ }^{41}$ From this point of view, Wolff argued that the obligation of state was to care about the education which would provide the subjects not only with various obligations (towards God, themselves and others), ${ }^{42}$ but also with the instructions of so-called 3Rs (reading, writing and arithmetic). ${ }^{43}$ Parents would have also been obliged to educate their children. ${ }^{44}$ Moreover, Wolff mentioned how the poor children were to receive their education and then the way in which also the orphanage should have been built in the state, where the orphans could get the necessary and useful knowledge in order to survive by themselves. ${ }^{45}$ In addition to his argument concerning orphanage, school for the poor children should have also been constructed in the state, where not only boys, but also girls could receive the education. ${ }^{46}$ And then, due to his emphasis on the labour and utility of human, begging was to be prohibited among people who were healthy and could work. In case they were willing to work, the state was obliged to give them working opportunities. If not, however, they should have been accommodated in a work house, where they would be compelled to work. ${ }^{47}$

Wolff discussed the point of charity from two perspectives of the obligation toward others and the right to property. As for the first according to him, people were obliged by the natural law not only to get their own perfection, but also to help the others to become perfect. ${ }^{48}$ In his work Vernünftige Gedancken von der Menschen Thun und Lassen he mentioned such obligation toward others based on his argument of the perfectibility under the natural law as follows: „Because human can only intend to do good: and the

39 Ibidem.

40 Ibidem, $\S 13$.

$41 \quad$ Ibidem, $§ 421$.

42 Ibidem, $\S 426$.

43 Ibidem, $\S 431$. For the history of education system in Prussia and Austria see James Van Horn Melton, Absolutism and the Eighteenth-Century Origins of Compulsory Schooling in Prussia and Austria, Cambridge 1988.

44 Ch. Wolf F, Jus naturae, $\S 430$.

45 Ibidem, $§ 742$.

46 Ibidem, $§ 744$.

47 Ibidem, $§ 737$.

48 Ch. Wolff, Grundsätze des Natur-und Volkerrechts, § 44. 
goodness is what makes us and our condition perfect. [... ] Hence, if he is supposed to do good for other's happiness, he must already be prepared to scoop up pleasure from his goodness for other, and thus, he must love other. "49 As Rassem has already mentioned, such argument on the benevolence toward others can be considered as the love of one's neighbours in Wolff's thought..$^{50}$ Moreover, the love drove humans to promote others' welfare, as much as they could. ${ }^{51}$ Based on such goodness for the others and for the purpose of attaining happiness, Wolff argued that humans were to give alms to those who were lack of ability to work in order their poor situation would be lightened to the others. ${ }^{52}$

Secondly, in Grundsätze des Naturund Volkerrechts Wolff discussed the theme of donation in its aspect of the right to property. ${ }^{53}$ According to him, not only the rich, but also the poor people could give alms in order to reduce misery of the needy, using their property. ${ }^{54}$ Thus, emphasising the labour and diligence of the subjects in his argument on the social care by the state, Wolff argued that the well-established state was to take care of the subjects helping them to acquire the necessary and useful knowledge to live on their own, and support them in getting a job and working. By contrast, the charity, such as giving alms, still remained in the sphere of private activities in his arguments.

\section{Cameralism and "Polizeywissenschaft": Johann H. G. von Justi ${ }^{55}$}

Adopting Leibnitzian method of the geometric deduction into his thought on state-building, Wolff contributed to promotion of the science of government, which had influence on many of the political and economic thinkers in Germanspeaking territories. ${ }^{56}$ It is said that one of

„Weil der Mensch nur das Gute wollen kan (§ 506. Met.): das Gute aber dasjenigen ist, was uns und unseren Zustand vollkommener machet $(\$ 422$. Met.)...Derowegen, wenn er eines andern Glückseeligkeit wollen soll; so muss er bereit seyn daraus Vergnügen zu schöpfen, und demnach den andern lieben ( $\$ 449$. Met.). “ Ch. Wolff, Vernünftige Gedancken von der Menschen Thun und Lassen, § 774. As for „Met.“ see his other work, Vernünffige Gedancken von Gott [...].

M. Rassem, Wohlfahrt, p. 617. As for Wolff's definition of the love of one's neighbours see Ch.

Wolff, Vernünftige Gedancken von der Menschen Thun und Lassen, § 774-777.

Regierung in Fünf Büchern, Frankfurt-Leipzig 1759; IDEM, Die Natur und das Wesen der Staaten, als die Grundwissenschaft der Staatskunst, der Policey, und aller Regierungswissenschaften, desgleichen als die Quelle aller Gesetze, Berlin-Stettin-Leipzig 1760; IDEM, Moralische und philosophische Schriften I-III, Berlin-Stettin-Leipzig 1760-1761; IDEM, Grundsätze der Policeywisseschaft, Göttingen 1782.

56 J. G. Backhaus, Christian Wolff on subsidiarity, p. 132. 
these thinkers influenced by his thought was Johann H. G. von Justi. ${ }^{57}$

Justi has been reckoned as a leading figure among cameralists and known as one of the founders of political economy. ${ }^{58} \mathrm{Ac}-$ cording to J. G. Backhaus and R. E. Wagner, the thought of cameralism developed in German-speaking territories during the $17^{\text {th }}$ and $18^{\text {th }}$ centuries, when central European countries were facing devastating wars and recovering from consequent damage. ${ }^{59}$ The cameralists put forward the necessity to produce economic growth in each of their states, increase the population and its welfare and then strengthen the power of their states. Justi moved ahead on these points of the cameralism. In 1750, with favourable estimations and strong expectations for Justi by Count Haugwitz, he moved to Vienna and then he was appointed as the professor for the cameralism and German rhetoric at Theresianum which was established in

Vienna in 1746 by Maria Theresa for preparing the future civil servants. ${ }^{60}$ Although it is said that the reputation of Justi's lecture at Theresianum was ambivalent, moreover his stay in Vienna as itself was rather short (1750-53), the basic framework of his thought was created during this period. ${ }^{61}$

Justi distinguished the activities of state towards the subjects from three points of view: the moral state of subjects; the provision for them in the civil state; the inner safety and justice for them with the purpose of rendering the subjects profitable for attaining the ultimate purpose of common happiness in the state. ${ }^{62}$ In his explanation of the provision for the subjects in the civil status Justi summarised the state provision for them in three more points as follows: providing them with the education and labour skills; preventing them from luxury, waste and abuse of property; preventing them from idleness and begging. ${ }^{63}$ In regard to the education for children, Justi argued that it had to be taken into consideration that children were to acquire writing and reading,

57 In regard to the influence of Wollf's thought on Justi, Jürgen G. Backhaus, From Wolff to Justi, in: idem (ed.), The Beginning of Political Economy. Johann Heinrich Gottlob von Justi, New York 2009, p. 1-18.

58 As for Justi's life and his political and economic thought, Ulrich ADAm, The Political Economy of J. H. G. Justi, Oxford-New York 2006; Erik S. Reinert, Johann Heinrich Gottlob von Justi-the life and times of an economist adventurer, in: J. G. Backhaus (ed.), The Beginning of Political Economy, p. 33-74.

59 J. G. Backhaus - Richard E. Wagner, The cameralists. A public choice perspective, Public Choice 53, 1987, p. 3-20.

60 In regard to Justi's lessons at Theresianum and its reputation, U. AdAm, The Political Economy, p. 26-39.

61 Ibidem, p. 34; Günther Chaloupex, J. H. G. Justi in Austria. His writings in the context of economic and industrial policies of the Habsburg Empire in the $18^{\text {th }}$ century, in: J. G. Backhaus (ed.), The Beginning of Political Economy, p. 147-156.

62 Johann H. G. von Justi, Grundsätze der Policeywisseschaft, § 17.

63 Ibidem, § 19. 
Christianity, working skills and duties of a good citizen and house holder because the welfare of "Republik" ${ }^{64}$ depended on abilities and skills of its future citizens. ${ }^{65}$ From this point of view, Justi denounced the idle people for disadvantage of the state and then he proposed some solutions to wipe idleness from people and make them diligent. Moreover, he argued that the "Landespolicey", which covered the commercial and economic activities of state in wide sense of "Policey" in his thought, ${ }^{66}$ was to pay attention to the various aspects of civil life to promote order and industriousness of people. ${ }^{67} \mathrm{He}$ even suggested that it might be better to impose a head tax, (Kopfsteuer), which would be levied on the idle people, who would not work, because otherwise they would be a burden on the state. ${ }^{68}$

Justi argued that it was in accordance with the obligations of philanthropy (Pfichten der Menschenliebe) to give some aid to those who suffer from poor situation. ${ }^{69}$ From this perspective, it was the obligation for the well-established state to take care of those who were in poor situation for the reason that they were too old and handicapped, or fell into poverty by some miseries. ${ }^{70}$ However, he pointed out that the poor-relief had been carried out in extremely unjust way so far. ${ }^{71} \mathrm{He}$ especially criticised the begging, insisting with a stern tone that begging, which was considered to cause the public disorder and idleness (which was a burden on the state), was never to be permitted in a well-established state. ${ }^{72}$ The beggars, according to Justi, knew the way how to evoke the feeling of compassion for them among the donators, which was to belong to the needy worthy of receiving the donation. ${ }^{73}$ Hence, the poor-relief did not depend on the grade of poor condition, but on the skills and experience of beggars. ${ }^{74}$ Therefore, for the purpose of the appropri-

64 In Der Grundriss der einer guten Regierung Justi argued that a state called „Republik“ was a society of people, who united together in order to promote their common happiness under a suprime power. J. H. G. Justi, Der Grundriss einer guten Regierung, § 7. According to Adam, Justi used the term of "Republik" for highlighting his concept of a modern monarchy, the rulers of which had obligation to take care of the welfare of their subjects. U. AdAm, The Political Economy, p. 17-18.

J. H. G. Justi, Grundsätze der Policeywisseschaft, § 304.

J. H. G. Justi, Die Natur und das Wesen der Staaten, § 272.

J. H. G. Justi, Grundsätze der Policeywisseschaft, § 328.

Ibidem, § 330 .

Ibidem, § 334. As for Justi’s view on the philanthropy see J. H. G. Justi, Moralische und philosophische Schriften I-III.

J. H. G. Justi, Grundsätze der Policeywisseschaft, § 334.

Ibidem.

Ibidem.

Ibidem.

Ibidem. 
ate and sufficient aid and care for the poor people who could have been considered to need it, the accommodation of them into special facilities was to be carried out in his argument. The state was to pay the operating expense of those facilities from the revenue. ${ }^{75}$

Moreover, the accommodation in such facilities was considered as a good way to enable making the measures against beggars effective. He mentioned that if people expected a good result of the ordinances against beggars, the poor people who were elder and handicapped would have to be accommodated into the special facilities such as hospitals or alms-houses. ${ }^{76}$ On the contrary to the poor people, beggars were to be accommodated in the facilities such as work houses. In regard to the running costs of work houses, the state was to pay only the costs for establishing it, the running costs should have been financed by labour of the inmates themselves. ${ }^{77}$

As mentioned above, Justi emphasised the utilisation of citizens as labourers by the state, because they were also considered to be the essential factor of the welfare of state itself, ${ }^{78}$ while he argued that the state was to take care of those who could not earn their own cost of living, due to the senility or disability, in the way of accommodation in the special facilities handling appropriate care for them.

\section{Joseph von Sonnenfels ${ }^{79}$}

Although Justi made his reputation as the leading thinker of cameralism and "Polizeywissenschaft", for example K. Tribe insists that it was Joseph von Sonnenfels who had more influence among the public than Justi. ${ }^{80}$ Because Sonnenfels's main work Grundsätze der Polizey, Handlung, und Finanz, the first edition of which was published in 1765, was reprinted again and again and it was furthermore used as a text book at the University of Vienna until 1848. In addition to his career as a lecturer at Theresianum and the University of Vienna Sonnenfels became an active member of Freemasonry which enabled him to be considered a representative

75 Ibidem, § 336 .

76 Ibidem.

77 Ibidem, § 337.

78 As for the change of view of the labour among the thinkers in early modern age see Hans FramВАСН, Cameralism and labour in von Justi's economic thinking, in: J. G. Backhaus (ed.), The Beginning of Political Economy, p. 133-145.

79 This article uses Sonnenfels's work as follows: Joseph von Sonnenfels, Grundsätze der Polizey, Handlung und Finanzwissenschaft, Vienna 1819.

80 Keith Tribe, Cameralism and the science of government, The Journal of Modern History 56, 1984, p. 263-284, here p. 275. On the general introduction of Sonnenfels's life see Helmut Reinalter, Joseph von Sonnenfels. Leben und Werk in Grundzügen, in: idem (ed.), Joseph von Sonnenfels, Vienna 1988, p. 1-9; H. Kremers (ed.), Joseph von Sonnenfels; Simon Karstens, Lehrer - Schriftsteller Staatsreformer. Die Karriere des Joseph von Sonnenfels (1733-1817), Vienna 2011. 
person of the reformers in the Habsburg Monarchy. Along with Bohemian mineralogist Ignaz von Born, who was the master of Masonic lodge in Vienna, „Zur wahren Eintracht", Sonnenfels was deputed to publish the Journal für Freymaurer in which he discussed on the relationships between society and Freemasonry from the perspective of morality. ${ }^{81}$

In his work Grundsätze der Polizey Sonnenfels explored the causes of various problems in the civil life such as disorder and poverty, and then he discussed on the role of state for the purpose of solving these problems and promoting safety and welfare of citizens, based on his definition of „Polizey“ which was „to establish and manage the internal safety “. ${ }^{82}$ Sonnenfels argued that the state should have had the authority to order its citizens to labour under the condition that they had the ability to work and were not lack of means to get own cost of living. On the other hand, those who could not work should have had the right to demand some support from their state. ${ }^{83}$ From this point of view he explained the sort of poverty and the way of poor-relief, and then made a classification of them while he mentioned the way of reducing a burden of the poor-relief on the state. Moreover, he divided the poverty into „short-term“ and „continuous“ for the purpose of the systematisation and optimisation of the poor-relief. ${ }^{84} \mathrm{He}$ explained that the short-term poverty came from the situation that the unstable workers, such as day labour, could not earn any money for the temporary reason of illness of themselves or their family. Such temporary disability to work could have made them more desperate towards labour. Therefore, he argued that it was not only obligatory, but also beneficial for the state to give them the support by means of distribution of aid to them from „Armenkasse“ - a poor-relief fund. ${ }^{85}$

The continuous poverty included the state officers who could not work because of health problems and old age, widows of the officers and day labourers who lost their ability to work. ${ }^{86}$ Sonnenfels suggested three types of provision of aid to them: a pension for the state officers,

81 On Sonnenfels's career as the leading member of Freemasonry in Vienna and his discussion on promotion of morality among the members of Freemasonry see Andreas Önnerfors, Freemasonry and civil society. Reform of manners and the Journal für Freymaurer (1784-1786), in: I. Cerman R. Krueger - S. Reynolds (edd.), The Enlightenment in Bohemia, p. 111-127. „Die innere Sicherheit zu gründen und zu handhaben [...]“ H. Reinalter, Joseph von Sonnenfels, p. 4. „Vorausgesetzt, dass durch geschickte Leitung der Handlung und Gewerbe, es dem Arbeitfähigen nicht an Mitteln gebricht, seinen Unterhalt zu erwerben, so ist die öffentliche Verwaltung zu jedem Bürger, der arbeiten kann, berechtigt zu sagen: Arbeite, um deinen Unterhalt selbst zu erwerben!' Aber auch jeder Bürger, der zur Arbeit unvermögend ist, hat das Recht vom Staate zu fordern: Gib mir Unterhalt! Da ich durch Arbeit mir solchen selbst nicht erwerben kann."J. von Sonnenfels, Grundsätze der Polizey, § 247. Ibidem.

85 Ibidem, § 248.

86 Ibidem, $\S 251$. 
a fund for widows of the officers, and for workers. ${ }^{87}$ The state had obligation to take care of the officers in the way of providing the officers with the pension. The state was also obligated to take care of their widows, but the way of provision for them was, as mentioned above, the fund for them. In short, it was not the state, but the officers who were to come up with the money for their widows. ${ }^{88}$ As for the fund for the workers, it was their masters or employers who were obligated to take care of their workers who were too old to work. Hence, Sonnenfels insisted that the state should have just had to pay attention to those masters or employers in order that they would carry out their obligation carefully. Otherwise, the burden of unaided persons would fall on the state. ${ }^{89}$

In Sonnenfels's argument the poor people who were considered as rightful to demand the social care of state were divided into three types: invalids (unbrauchbare Soldaten), poor inhabitants in towns, and in rural areas. ${ }^{90} \mathrm{He}$ explained that the poor-relief for them had the common principle; the provision of care had to be distributed to those in need worthy of it with reliability; it had to be provided without abandonment of the sufficiency and at least cost. ${ }^{91}$ Based on the principle, therefore he argued that the accommodation in the facilities was more preferable to the relief from the poor-relief fund and the donation by hand for those who could not work and get their own living cost. ${ }^{92}$

It was the appropriate distribution as well as the efficiency of relief for the poor people together with lesser burden on the state that Sonnenfels tried to improve with regards to the poor-relief. The accommodation in the facilities should have allowed the poor people to receive the sufficient and appropriate care for them at lower cost in the facilities in comparison with the poor-relief fund and the donation by hand. Because for example in case of the donation by hand, the begging persons, even if they were considered not to be worthy of receiving the donation, could receive more amount of the donation than they needed exactly, or they could not receive enough sustenance by the donation..$^{93}$ In addition to this, Sonnenfels suggested that it was supposed to be beneficial for the facilities to share conjointly the necessities, such as habitation, wood, light, meal, among the inmates in order to reduce the costs of running such facilities. ${ }^{94}$
87 Ibidem.
88 On the system of the pension for the state officers and the fund for their widows see ibidem, $\S 252-255$.
89 Ibidem, $§ 252$.
90 Ibidem, $§ 257$.
91 Ibidem.
92 Ibidem.
93 Ibidem, § 258 .
94 Ibidem. 
As for the financial source for running them, the facilities should have been financed by the taxes from transportation, game and so on. ${ }^{95}$ However, Sonnenfels mentioned that they should have certainly had to ensure the income as well as expense. ${ }^{96}$ Therefore Sonnenfels argued that the expense of the facilities was to be counted into the expense of state. Hence, it should have been financed mainly by the state, and then carried by the all citizens with care and attention. ${ }^{97}$

Sonnenfels strictly criticised idleness, begging and even donations by hand..$^{98}$ In order to exclude the idleness and begging from people, he suggested, for instance, that the clergies were supposed to teach people that "the donation, which they give to individuals who are able to work, is far from being worthy of praise, it is rather a nourishment for idleness..." ${ }^{\text {"99 }}$ Moreover, he advanced his opinion that if the poor people, who could not earn their own living costs because of senility or disability, received aid and support, there was not any reason for begging to be permitted by the state. ${ }^{100}$ Therefore, he argued that the donation by hand on streets, in churches, houses and monasteries should have been obviated. ${ }^{101}$

\section{Conclusion}

As stated above, in the argument on the poor-relief by the natural law thinkers, especially Wolff, the function of state and rulers was auxiliary. They insisted that the state and the rulers should take care of the distribution of opportunity for the citizens to receive the education for their future life or to labour, and get necessary sustenance to be able to take care of themselves, while the state and the rulers should give aid to the poor people who could not work. Hospitals or speciall facilities would be the instruments of this social care. Their argument was taken over by the thinkers of cameralism and the science of government (Polizeywissneschaft).

However, there was a great difference between the natural law thinkers and the thinkers of cameralism and science of government. Wolff conceived of the charitable activities as endowments that would not violate anybody's right to property. On the contrary, Sonnenfels prohibited charitable donation as a whole. He tried to desacralise the poor-relief in which the church played the main role until then. Furthermore, he argued that it should be supervised by the state. In doing so, the state would implement the welfare

Ibidem, § 259.

Ibidem.

Ibidem.

Ibidem, § 258.

„Dass der Geistlichkeit aufgetragen werde, das Volk zu belehren: Almosen, welches sie, zu Arbeit tauglichen Menschen, geben, weit entfernt, ein verdienstliches Werk zu seyn, sey vielmehr eine Nahrung des Müssigganges..." Ibidem, $§ 100$.

Ibidem, § 101 .

Ibidem. 
policy as a means to direct the poor-relief. However, it should not be ignored that Sonnenfels himself did not argue that the state should intervene into all the aspects of civil life. Rather he tried to promote the self-help among the citizens through the introduction of the welfare system for the poor people such as the fund for widows and workers. Moreover, the fund was supposed to be supplied from the monthly contribution in a similar fashion as the insurance premium today.

It would be useful to compare these views with those of Christian theologians and priests who also influenced social policies in the Habsburg Monarchy in the times of Maria Theresa and Joseph II. So far, it seems that they also insisted on the importance of labour and believed that poverty and beggary would be aleviated if beggars and poor people were better motivated to work. For instance, Ludovico Antonio Muratori recommended the poor people to labour by quoting the words from the Book of Job: "the human was born to work, as the bird was born to fly" ${ }^{102}$ In addition to this, they also thought that the common good in the state could be upheld by the multiplication of work force and the promotion of the well-ordered status among the poor people through the system of the poorrelief. For example the Josephine moral theologian Augustin Zippe believed that. However, in contrast with the secular thinkers, the Christian religious thinkers put more emphasis on individual Chritian virtues, namely charity. They urged citizens to follow the principles, 'love your neighbours as brother', and then 'come to the poor people to help', in other words, the active and effective practice of the charity.

Thus, it should be worth reconsidering the welfare state in the era of the Enlightenment from the point of view of Christian morality, namely the opinions on charity. In doing so, there should be more opportunity to focus on the aspects of poor-relief from 'below'. Moreover, the reconsideration could also shed new light on the scheme of the enlightened absolutism and the cliché that its reforms were conducted from 'above'.

${ }^{102}$ Ludovico Antonio Muratori, Gründliche Auslegung des grossen Gebotbs von der Liebe des Nächsten; aus dem Italien, Augsburg 1768, p. 719. 


\section{Yuki Haruyama}

\section{The Question of Welfare State in Natural Law Theories}

The contribution points to the fact that the historical research in German historiographies has already revealed the evolution of the idea of the welfare state in the reforms of englihtened absolutism. In this research Christian Wolff has played an important part; he contributed to the establishment of the ideas of public assistance within the scope of natural law. The contribution aims to be a part of those research results. Furthermore, it comes with a revised approach towards the importance of charity. Charity did not only gain moral value but it was a fundamental source of wealth. To follow the evolution of the idea of public assistance of the state and the change of opinion in terms of charity, the contribution deals with Pufendorf's, Wollf's, Justi's and Sonnenfels's arguments, as in their theories the Habsburg Monarchy revealed its motivation for state leadership. When it came to poor-relief, those thinkers argued that the state is obliged to provide its citizens with educational opportunities and also employment so that they could become independent and stand on their own feet. The state is also obliged to care for the poor who are unemployed and cannot earn their living because of their physical or mental disabilities or senility. When it came to the issue of charity, those philosophers were dissenting. Samuel von Pufendorf and Christian Wolff admitted that charity has moral values whereas Josef von Sonnenfels banned charitable donations. For the ongoing research it will be advantageous to compare those arguments with the Christian point of view in terms of welfare and charity in the Habsburg Monarchy.

KEY WORDS:

natural law; political science; social obligations of the state; poor-relief; charity 